\title{
Nutritional requirements during ageing
}

\author{
Jean-Michel Lecerf ${ }^{1,2, *}$ \\ ${ }^{1}$ Service de Nutrition - Institut Pasteur de Lille, 1 rue du Professeur Calmette, 59019 Lille Cedex France \\ 2 Service de Médecine Interne-CHRU de Lille, 59037 Lille Cedex, France
}

Received 25 January 2019 - Accepted 22 March 2019

\begin{abstract}
Ageing is a physiological condition characterized by a decline of the adaptatives capacities and associated to a decrease of the lean mass. That one is due to a decrease of the post-prandial protein synthesis. It is why protein recommended allowances must be sufficient for a quantitative aspect $(0.8-1.2 \mathrm{~g} / \mathrm{kg} / \mathrm{d})$ and adapted for a qualitative point of view. Energy requirements do not decrease with age if the physical activity is unchanged: it is why the carbohydrate and lipid intakes must be similar to those of a younger adult. The quality of the carbohydrate intake and the distribution of the fatty acids are also important in order to avoid any deficiency. Concerning non-energetic nutrients, one must be particularly cautious for the vitamin D and calcium intakes. Behind nutrients there are foods and dietary patterns who have their own effects.
\end{abstract}

Keywords: nutritional requirements / lean mass / protein intakes / elderly / ageing

Résumé - Les besoins nutritionnels au cours du vieillissement. Le vieillissement est une condition physiologique caractérisée par une perte des capacités d'adaptation et associée à une diminution de la masse maigre. Celle-ci est liée à une diminution de la synthèse protéique post-prandiale. C'est pourquoi les apports conseillés en protéines doivent être suffisants sur le plan qualitatif $(0,8-1,2 \mathrm{~g} / \mathrm{kg} / \mathrm{j})$ et satisfaisants sur le plan qualitatif. Les besoins énergétiques, quant à eux, ne diminuent pas à activité physique égale : c'est pourquoi les apports glucidiques et lipidiques doivent être maintenus à un niveau identique à ceux de l'adulte jeune. La qualité de l'apport glucidique et la répartition de l'apport lipidique sont également importants, en veillant à éviter tout déséquilibre en acides gras. En ce qui concerne l'apport en micronutriments non énergétiques, on veillera particulièrement à l'apport en vitamine $\mathrm{D}$ et en calcium. Au-delà des nutriments il y a les aliments, mais aussi les styles alimentaires qui ont des effets propres.

Mots clés : apports nutritionnels conseillés / masse maigre / apports protidiques / personnes âgées / vieillissement

\section{Introduction}

The dramatic increase of life expectancy achieving 85.4 years in women (and 79.4 years in men), instead of 37 years in 1810 , two centuries ago, and instead of 25 years in 1750 , associated to an increase of the baby-boom between 1945 and 1975 lead today to the papy boom and then to a very high number of subjects over 65 years. But the chronologic age do not allow to anticipate the health status, although ageing is a physiological process.

\section{Physiology of ageing}

Ageing is a decrease of the adaptive capacity in front of new situations or aggressions. For the digestive system, few

\footnotetext{
"Contribution to the Topical Issue "Lipids in the elderly: needs, nutrition and physiopathology / Les lipides pour les seniors : besoins, alimentation et physiopathologie"

*Correspondence: jean-michel.lecerf@pasteur-lille.fr
}

changes of digestive capacities, secretory or motricity are seen. However, it exists a lengthening of the satiety duration: that induces a spontaneous spacing of the food intakes or a reduction of the dietary intakes. Moreover, we observe a decrease of the perceived pleasure during the meals, meaning that there is a negative allesthesia which may reinforce the reduction of the amount of ingesta. Finally, it exists an increase of the detection level for smells and tastes which may also modify appetite. All that may explain a loss of the adaptive capacity after under-feeding: indeed it is not followed by an increase of the dietary intakes, and that may explain the lack of return to the initial weight, in opposition with that is observed in younger subjects (Roberts et al., 1994; Moriguti et al., 2000). Similarly, in the case of over-feeding there are few reductions of the dietary intakes on the next meal and that could contribute to a weight gain (Rolls et al., 1995).

The main ageing metabolic characteristic is the decline of the lean mass, that is to say essentially the muscle and bone mass. Although it is physiological, and begins early in the life, 
that may lead to sarcopenia and osteopenia, sometimes called osteo-sarcopenia characterized by a progressive global loss of the muscle mass and strength, associated to a higher risk of declining physical performances, an alteration of the quality of life and to an increase of morbidity and mortality (Fielding et al., 2011; Cao and Morley, 2016). Its causes are numerous. Among them the lesser capacity of the post-prandial protein synthesis linked to the age, is a major explanation (Visser and Schaap, 2011). Moreover, some circumstances require to increase the protein synthesis in order to recover the alteration of the lean mass. The reduction of the lean mass contributes to the lesser resistance to infections and aggressions. It is also responsible of the decrease of the basal metabolism and therefore of the energy expenditure; it is inversely correlated to an increase of the fat mass. It is associated to a decrease of the muscle strength with age (Lauretani et al., 2003).

\section{Energy and protein requirements}

If the physical activity is unchanged the energy requirements are not diminished with age. However, the protein requirements are enhanced in order to compensate for the reduction of the muscle protein synthesis. In a three years longitudinal study (Health ABC Study) (Houston et al., 2008), the reduction of the lean mass linked to the age decreases in parallel to the increase of the protein intakes in absolute value (from 57 to $91 \mathrm{~g} / \mathrm{d}$ ) or relative value (from 11 to $19 \%$ ). Similarly, in a cross-sectional study in elderly women aged 60-90 years the muscle strength is higher and the physical performance is higher in the women eating more than $0.8 \mathrm{~g} / \mathrm{kg} / \mathrm{g}$ of proteins (Gregorio et al., 2014). It is why in healthy elderly people, the recommended dietary allowances for protein is 1.1 to $1.2 \mathrm{~g} / \mathrm{kg} / \mathrm{d}$, instead of 0.83 to $1.0 \mathrm{~g} / \mathrm{kg} / \mathrm{d}$ in younger subjects (Martin, 2018). However, in wellnourished men 65 years or older a recent study do not find difference for lean mass between 0.83 or $1.3 \mathrm{~g} / \mathrm{kg} / \mathrm{d}$ of protein; but i) the lean mass was high initially; ii) the fat mass has decreased with $1.3 \mathrm{~g} / \mathrm{kg} / \mathrm{d}$ of protein; iii) all subjects received $1260 \mathrm{mg}$ calcium and 1000 vitamin D; iv) the lean mass do not reflect the strength nor the function (Bhasin et al., 2018).

The decrease of the post-prandial protein synthesis is due to an elevation of the anabolic threshold in the elderly. This threshold depends from the aminoacidemia particularly from the leucinemia (Katsanos et al., 2006; Paddon-Jones et al., 2006). The elevation of the threshold is due to the splanchnic sequestrations of amino acids in the liver and the intestine, leading to a lesser bioavailability of the amino acids and particularly of leucine for the protein synthesis. The balance between protein anabolism and catabolism may also be influenced by other factors, physiological factors or not. The anabolism is altered by the insulin resistance, the reduction of anabolic hormones (testosterone, growth hormone, IGF1), the vitamin $\mathrm{D}$ deficiency, the physical inactivity, the mitochondrial dysfunction and the inflammatory process. Catabolism may be increased by aggressions and tissue losses (wounds, burns slough, ulcers, fractures, cicatrisation...), or by an excess of physical activity...

So, not only quantitative intake but also qualitative aspects are important for the protein synthesis. In order to exceed the anabolic threshold, fast proteins which increase more the aminoacidemia are specifically of interest. It is well-known that lactoserum proteins are fast proteins (Boirie et al., 1997; Dangin et al., 2003); they are rich in leucine and trigger more the protein synthesis than casein and are more efficiency in order to limit the muscle protein losses in the elderly (Pennings et al., 2011; Bergia et al., 2018). A recent cross-sectional study in women older than 65 years confirms that the animal protein intakes, and particularly the dairy protein intakes are correlated to the bone strength microstructure (Durosier-Izart et al., 2017). That confirm the former data of the prospective study (Iowa Women's Health Study) (Munger et al., 1999) showing that the risk of femoral neck fracture decreases while the total and animal protein intakes increase.

Energy intakes and protein metabolism are linked. It is well established that it exists a sparing nitrogen effect of carbohydrates and then of caloric intakes. It is why in overweight elderly subjects, any energy reduction is always accompanied by a lean mass loss, in absolute or relative value, even if it is associated by exercise (Weinheimer et al., 2010).

Don't forget finally that there is no proven data that energy restriction increases the life expectancy in primates, in opposition with that is often said; in interventional studies the control group is overfeed or has a bad diet, and the experimental group is supplemented (Le Bourg, 2018; Moore, 2018). Classically, a caloric restriction under 1500 Kcalories without deficiencies is not possible in human. The only one interventional study with a long duration restrictive diet in human has shown a weight loss and a general health alteration (Le Bourg, 2012).

\section{Nutritional requirements for lipids and carbohydrate}

The percentage of energy from fat is similar in elderly and in younger adults (35 to 40\%) (ANSES, 2011). It must not be smaller because it is necessary to maintain recommended essential fatty acid allowances. Saturated fatty acids (particularly from dairy source) intake must be sufficient in order to maintain a sufficient intake of myristic acid (Jan et al., 2004; Drouin et al., 2018): indeed this fatty acid increases the desaturases activity for the biotransformation of linoleic and alphalinolenic acids into long chain polyunsaturated fatty acids.

Moreover, if the saturated fatty acid intake is too low, it could facilitate alpha linolenic acid $\beta$ oxidation. In reality, it is necessary to maintain simultaneously sufficient intakes of alphalinolenic acid (as a precursor of longer fatty acids) because there is a decrease of the desaturases activity with age and sufficient intakes of long chain omega 3 fatty acids (EPA and mainly DHA): indeed DHA is a major fatty acid for structural and functional retina (Souied et al., 2015) and brain (Andrieu et al., 2017). Overall, 1\% of the total energy for alphalinolenic acid and $4 \%$ for linoleic acid are necessary. For DHA, the requirement is of $250 \mathrm{mg} / \mathrm{d}$ and for total long chain omega 3 fatty acids it is of $500 \mathrm{mg} / \mathrm{d}$ (ANSES, 2011).

There are no specific requirements for carbohydrates in comparison with younger adults. Their consumption is fundamental for the nitrogen balance. The restrictive diets are negative for maintaining the lean mass. 
The quality of the carbohydrate intakes is also important to take into account. Many studies have shown an inverse relationship between glycemic index and/or glycemic load and Age Related Macular Disease incidence (Chiu et al., 2006, 2007a, b; Kaushik et al., 2008). A recent prospective study has shown that a high glycemic index diet and a high glycemic load are associated to a higher risk of osteoporotic fractures (García-Gavilán et al., 2018). Another study has found an association between free sugars and frailty (Laclaustra et al., 2018), and between sugar intakes and beta amyloid plaques accretion in the brain (Taylor et al., 2017).

\section{Micronutrient requirements}

Since energy intake is often reduced due to the appetite reduction and the satiety increase, and to the lesser physical activity, many elderly people eat approximatively $1500 \mathrm{kcal} / \mathrm{d}$ or less. That implies a diet with a high nutritional density (mg of a nutrient for $100 \mathrm{Kcal})$.

Calcium and vitamin D intakes are of great importance. Many studies show that a small calcium or a small intake of dairy products is associated with a higher risk of osteopenia and fractures (Prentice, 2014; Fung et al., 2017), even if the calcium intake is not very low. For instance in the Melbourne Collaborative Cohort Study (Khan et al., 2015), the fracture incidence was $30 \%$ higher in the lowest quartile when compared to the highest quartile of calcium intake $(641 \pm 121 \mathrm{mg} / \mathrm{d}$ versus $1076 \pm 163 \mathrm{mg} / \mathrm{d})$.

Although previous studies have demonstrated the efficacy of a vitamin D and calcium supplementation on the fracture incidence in home resident elderly subjects (Chapuy et al., 1992; Dawson-Hughes et al., 1997) a recent meta-analysis on the interventional trials with vitamin $\mathrm{D}$ alone (after the age of 18 years old) do not show a preventive effect on the occurrence of fracture and fall (Bolland et al., 2018). The issue of the dose is raised in that paper since there is probably no benefit to high and spaced doses of vitamin D. Moreover, supplementation should be given to vitamin $\mathrm{D}$ deficient patients, who have a reduced muscle function and walk speed. It is well-known that this last parameter is a good survival marker in the elderly (Studenski et al., 2011).

\section{Weight and body composition}

All these data show that the continuation of a physical activity is the best way for maintaining sufficient energy intake in order to allow the achievement and the coverage of the nonenergetic requirements (micronutrients) mainly if the nutritional density is not so high. Moreover, this allows to keep a stable weight and a good lean body mass.

Many studies have shown that in the elderly a moderate overweight is associated with a lesser mortality (Stevens et al., 1998). Other studies have shown a higher post-surgery mortality for a small body mass index (BMI) compared to a higher BMI (Koster et al., 2008; Mullen et al., 2009; Valentijn et al., 2013). A prospective study has demonstrated that a weight loss in elderly subjects with metabolic abnormalities was associated with an increase of mortality (Dong et al., 2018). Similarly, a low muscle strength increases mortality, whatever the weight confirming the major role of the muscle mass. The negative role of sarcopenia in obesity has been proven on mortality as soon as 2008 (Prado et al., 2008; Zamboni et al., 2008). Obesity with sarcopenia is the most insidious form of sarcopenia with its negative consequences on physical incapacity (Baumgartner, 2000) and on functional disability Baumgartner et al., 2004).

So it is fundamental to maintain stable weight in older subjects with normal weight and to obtain sufficient protein and energy intakes and then to maintain a regular physical activity. In case of obesity in the elderly, it is necessary to screen and prevent sarcopenia.

\section{Dietary patterns}

Behind the nutrient intakes, a global or holistic approach is essential. The dietary patterns reflect the dietary complexity. It includes both the matrix effect (Thorning et al., 2017) linked to the food and the dietary variety. So, for example, it has been shown that a better diet quality (with high intake of vegetables, fruits, whole grains, legumes, nuts, dairy products, fish and low intake of sugar-containing beverages) is related to larger brain tissue volumes (gray matter, white matter, hippocampal volumes) (Croll et al., 2018). Similarly, the Mediterranean diet is not only associated to a lesser prevalence of the agerelated cognitive decline, but it has been shown in randomized controlled trials with a Mediterranean diet a lower risk of lowplasma brain derived neurotrophic factor (BDNF) which promotes connectivity between neurons (Radd-Vagenas et al., 2018). Among women aged $\geq 60$ years with type 2 diabetes a Mediterranean style diet pattern is associated with a reduced risk of frailty syndrome in a recent large prospective study (Lopez-Garcia et al., 2018).

\section{No nutritive needs}

Eat has not only nutritive functions, and nutrient requirements are not the only one dietary needs. Non-nutritive needs are in interaction with the previous. These are hedonic and psychological functions (with the eating pleasure) and social and relational functions. They greatly contribute to sufficient dietary intakes and to the coverage of the nutrient requirements. They must be taken into account for an optimized diet.

\section{Conclusion}

The nutritional requirements during ageing are not so far different from those of younger adults. However, some cautions must be taken, particularly to avoid non-sufficient intakes in proteins and in energy. Indeed, there is a decrease of the lean mass due to the decrease of the post-prandial protein synthesis, so the protein needs must be increase in order to compensate that. Moreover, there is a potential vicious circle for the energy balance due to the decrease of the resting metabolism and of the physical activity. Since carbohydrate energy source may improve the protein balance by a nitrogen sparing, it must be also preserve. Finally, the fatty acids variety is also of consequence for health, mainly the essential fatty acids. A focus must be done on non-energetic nutrients, whose intakes depend on the diet variety and the nutritional density. No food groups must be removed, particularly fish, meat and 
dairy products for omega 3 fatty acids, proteins, iron, and calcium.

Conflicts of interest. The author declares that he has no conflicts of interest in relation to this article.

\section{References}

Andrieu S, Guyonnet S, Coley N, et al. 2017. Effect of long-term omega 3 polyunsaturated fatty acid supplementation with or without multidomain intervention on cognitive function in elderly adults with memory complaints (MAPT): A randomised, placebocontrolled trial. Lancet Neurol 16: 377-389.

ANSES. 2011. Actualisation des apports nutritionnels conseillés pour les acides gras. Rapport d'expertise collective.

Baumgartner RN. 2000. Body composition in healthy aging. Ann NY Acad Sci 904: 437-448.

Baumgartner RN, Wayne SJ, Waters DL, et al. 2004. Sarcopenic obesity predicts instrumental activities of daily living disability in the elderly. Obes Res 12: 1995-2004.

Bergia RE, Hudson JL Campbell WW. 2018. Effect of whey protein supplementation on body composition changes in women: A systematic review and meta-analysis. Nutr Rev 76: 539-551.

Bhasin S, Apovian CM, Travison TG, et al. 2018. Effect of protein intake on lean body mass in functionally limited older men. JAMA Intern Med 178: 530.

Boirie Y, Dangin M, Gachon P, Vasson MP, Maubois JL, Beaufrère B. 1997. Slow and fast dietary proteins differently modulate postprandial protein accretion. Proc Natl Acad Sci U S A 94: 14930-14935.

Bolland MJ, Grey A, Avenell A. 2018. Effects of vitamin D supplementation on musculoskeletal health: A systematic review, meta-analysis, and trial sequential analysis. Lancet Diabetes Endocrinol 6: 847-858.

Cao L, Morley JE. 2016. Sarcopenia is recognized as an independent condition by an international classification of disease, Tenth Revision, Clinical Modification (ICD-10-CM) Code. J Am Med Dir Assoc 17: 675-677.

Chapuy MC, Arlot ME, Duboeuf F, et al. 1992. Vitamin D3 and calcium to prevent hip fractures in elderly women. $N$ Engl $\mathrm{J} \mathrm{Med}$ 327: $1637-1642$.

Chiu C-J, Hubbard LD, Armstrong J, et al. 2006. Dietary glycemic index and carbohydrate in relation to early age-related macular degeneration. Am J Clin Nutr 83: 880-886.

Chiu C-J, Milton RC, Gensler G, Taylor A. 2007a. Association between dietary glycemic index and age-related macular degeneration in nondiabetic participants in the Age-Related Eye Disease Study. Am J Clin Nutr 86: 180-188.

Chiu C-J, Milton RC, Klein R, Gensler G, Taylor A. 2007b. Dietary carbohydrate and the progression of age-related macular degeneration: A prospective study from the Age-Related Eye Disease Study. Am. J Clin Nutr 86: 1210-1218.

Croll PH, Voortman T, Ikram MA, et al. 2018. Better diet quality relates to larger brain tissue volumes: The Rotterdam Study. Neurology 90: e2166-e2173.

Dangin M, Guillet C, Garcia-Rodenas C, et al. 2003. The rate of protein digestion affects protein gain differently during aging in humans. J Physiol 549: 635-644.

Dawson-Hughes B, Harris SS, Krall EA, Dallal GE. 1997. Effect of calcium and vitamin D supplementation on bone density in men and women 65 years of age or older. N Engl J Med 337: 670-676.
Dong S-Y, Wang, M-L, Li Z-B, et al. 2018. Obesity, weight change, and mortality in older adults with metabolic abnormalities. Nutr Metab Cardiovasc Dis 28: 749-755.

Drouin G, Catheline D, Sinquin A, et al. 2018. Incorporation of dairy lipids in the diet increased long-chain omega-3 fatty acids status in post-weaning rats. Front Nutr 5: 42.

Durosier-Izart C, Biver E, Merminod F, et al. 2017. Peripheral skeleton bone strength is positively correlated with total and dairy protein intakes in healthy postmenopausal women. Am J Clin Nutr 105: 513-525.

Fielding RA, Vellas B, Evans WJ, et al. 2011. Sarcopenia: An undiagnosed condition in older adults. Current consensus definition: Prevalence, etiology, and consequences. International working group on sarcopenia. J Am Med Dir Assoc 12: 249-256.

Fung TT, Meyer HE, Willett WC, Feskanich D. 2017. Protein intake and risk of hip fractures in postmenopausal women and men age 50 and older. Osteoporos Int 28: 1401-1411.

García-Gavilán JF, Bulló M, Camacho-Barcia L, et al. 2018. Higher dietary glycemic index and glycemic load values increase the risk of osteoporotic fracture in the PREvención con DIeta MEDiterránea (PREDIMED)-Reus trial. Am J Clin Nutr 107: 1035-1042.

Gregorio L, Brindisi J, Kleppinger A, et al. 2014. Adequate dietary protein is associated with better physical performance among post-menopausal women 60-90 years. J Nutr Health Aging 18: $155-160$.

Houston DK, Nicklas BJ, Ding J, et al. 2008. Dietary protein intake is associated with lean mass change in older, community-dwelling adults: The Health, Aging, and Body Composition (Health ABC) Study. Am J Clin Nutr 87: 150-155.

Jan S, Guillou H, D'Andrea S, et al. 2004. Myristic acid increases delta6-desaturase activity in cultured rat hepatocytes. Reprod Nutr Dev 44: 131-140.

Katsanos CS, Kobayashi H, Sheffield-Moore M, Aarsland A, Wolfe RR. 2006. A high proportion of leucine is required for optimal stimulation of the rate of muscle protein synthesis by essential amino acids in the elderly. Am J Physiol Endocrinol Metab 291: E381-E387.

Kaushik S, Wang JJ, Flood V, et al. 2008. Dietary glycemic index and the risk of age-related macular degeneration. Am J Clin Nutr 88: $1104-1110$

Khan B, Nowson CA, Daly RM, et al. 2015. Higher dietary calcium intakes are associated with reduced risks of fractures, cardiovascular events, and mortality: A prospective cohort study of older men and women. J Bone Miner Res 30: 1758-1766.

Koster A, Leitzmann MF, Schatzkin A, et al. 2008. Waist circumference and mortality. Am J Epidemiol 167: 1465-1475.

Laclaustra M, Rodriguez-Artalejo F, Guallar-Castillon P, et al. 2018. Prospective association between added sugars and frailty in older adults. Am J Clin Nutr 107: 772-779.

Lauretani F, Russo CR, Bandinelli S, et al. 2003. Age-associated changes in skeletal muscles and their effect on mobility: An operational diagnosis of sarcopenia. J Appl Physiol 95: 18511860.

Le Bourg É. 2012. Restriction de nourriture, longévité et vieillissement. Cah Nutr Diététique 47: 85-92.

Le Bourg E. 2018. Does calorie restriction in primates increase lifespan? Revisiting Studies on macaques (Macaca mulatta) and mouse lemurs (Microcebus murinus). Bioessays 40: e1800111.

Lopez-Garcia E, Hagan KA, Fung TT, Hu FB, Rodríguez-Artalejo F. 2018. Mediterranean diet and risk of frailty syndrome among women with type 2 diabetes. Am J Clin Nutr 107: 763-771. 
Martin A. 2018. The "apports nutritionnels conseillés (ANC)" for the French population $3^{\mathrm{e}}$ édition (retirage 2018). Reprod Nutr Dev 41: $119-128$.

Moore A. 2018. Calorie restriction off the menu for the time being?... Bioessays 40: e1800170.

Moriguti JC, Das SK, Saltzman E, et al. 2000. Effects of a 6-week hypocaloric diet on changes in body composition, hunger, and subsequent weight regain in healthy young and older adults. $J$ Gerontol A Biol Sci Med Sci 55: B580-7.

Mullen JT, Moorman DW, Davenport DL. 2009. The obesity paradox: Body mass index and outcomes in patients undergoing nonbariatric general surgery. Ann Surg 250: 166-172.

Munger RG, Cerhan JR, Chiu BC. 1999. Prospective study of dietary protein intake and risk of hip fracture in postmenopausal women. Am J Clin Nutr 69: 147-152.

Paddon-Jones D, Sheffield-Moore M, Katsanos CS, Zhang X-J, Wolfe RR. 2006. Differential stimulation of muscle protein synthesis in elderly humans following isocaloric ingestion of amino acids or whey protein. Exp Gerontol 41: 215-219.

Pennings B, Boirie Y, Senden JM, Gijsen AP, Kuipers H, van Loon LJ. 2011. Whey protein stimulates postprandial muscle protein accretion more effectively than do casein and casein hydrolysate in older men. Am J Clin Nutr 93: 997-1005.

Prado CM, Lieffers JR, McCargar LJ, et al. 2008. Prevalence and clinical implications of sarcopenic obesity in patients with solid tumours of the respiratory and gastrointestinal tracts: A population-based study. Lancet Oncol 9: 629-635.

Prentice AM. 2014. Dairy products in global public health. Am J Clin Nutr 99: 1212S-1216S.

Radd-Vagenas S, Duffy SL, Naismith SL, Brew BJ, Flood VM, Fiatarone Singh MA. 2018. Effect of the Mediterranean diet on cognition and brain morphology and function: A systematic review of randomized controlled trials. Am J Clin Nutr 107: 389-404.
Roberts SB, Fuss P, Heyman MB, et al. 1994. Control of food intake in older men. J Am Med Assoc 272: 1601-1606.

Rolls BJ, Dimeo KA, Shide DJ. 1995. Age-related impairments in the regulation of food intake. Am J Clin Nutr 62: 923-931.

Souied EH, Aslam T, Garcia-Layana A, et al. 2015. Omega-3 fatty acids and age-related macular degeneration. Ophthalmic Res 55: 62-69.

Stevens J, Cai J, Pamuk ER, Williamson DF, Thun MJ, Wood JL. 1998. The effect of age on the association between body-mass index and mortality. $N$ Engl J Med 338: 1-7.

Studenski S, Perera S, Patel K, et al. 2011. Gait speed and survival in older adults. JAMA 305: 50-58.

Taylor MK, Sullivan DK, Swerdlow RH, et al. 2017. A high-glycemic diet is associated with cerebral amyloid burden in cognitively normal older adults. Am J Clin Nutr 106: 1463-1470.

Thorning TK, Bertram HC, Bonjour J-P, et al. 2017. Whole dairy matrix or single nutrients in assessment of health effects: Current evidence and knowledge gaps. Am J Clin Nutr 105 : 1033-1045.

Valentijn TM, Galal W, Hoeks SE, van Gestel YR, Verhagen HJ, Stolker RJ. 2013. Impact of obesity on postoperative and longterm outcomes in a general surgery population: A retrospective cohort study. World J Surg 37: 2561-2568.

Visser M, Schaap LA. 2011. Consequences of sarcopenia. Clin Geriatr Med 27: 387-399.

Weinheimer EM, Sands LP, Campbell WW. 2010. A systematic review of the separate and combined effects of energy restriction and exercise on fat-free mass in middle-aged and older adults: Implications for sarcopenic obesity. Nutr Rev 68: 375-388.

Zamboni M, Mazzali G, Fantin F, Rossi A, Di Francesco V. 2008. Sarcopenic obesity: A new category of obesity in the elderly. Nutr Metab Cardiovasc Dis 18: 388-395.

Cite this article as: Lecerf J-M. 2019. Nutritional requirements during ageing. OCL 26: 22. 